\title{
The Mediterranean Buffalo: an Under Estimated Dairy Ruminant Species
}

\author{
Paolo Ciaramella* \\ Department of Veterinary Medicine and Animal Productions, University of Napoli Federico II, Italy
}

Submission: February 06, 2017; Published: February 13, 2017

*Corresponding author: Paolo Ciaramella, Department of Veterinary Medicine and Animal Productions, University of Napoli Federico II, Internal Medicine Section, Via F Delpino 1, 80137, Napoli, Italy, Email: PAOCIARA@unina.it

\section{Editorial}

Mediterranean buffalo's (MB) milk production represents one of the most important Italian rural economies and assets. The economic activities linked with buffalo milk and mozzarella cheese, represent the $4^{\circ}$ food-economy for sales volume in the entire country (more of 320 million of euro and more of 15000 workers) being widely sold all over the Europe.

The $80 \%$ of buffalo milk is used for mozzarella cheese production; this fresh product is, for the major part, produced by Protected Origin area (PDO - Campania, Puglia, Molise and Lazio regions) although few animals are bred in others Italian regions (e.g. Veneto, Piemonte and Lombardia) in north of Italy and in EU-countries (e.g. Switzerland, Romania, Turkey), showing an increasing interest in this rural business. However the PDO represents a leader example in this sector.

Considering the sales volume, it is important to guarantee the safety of theconsumers by means the protection of Mediterranean buffalo udder health. Dairy MB has been associated to dairy cow for a long time; as consequence these ruminants have been long underestimated under a scientific point of view.

In spite of the continuous controls by the veterinary public health, who guarantee the quality and the healthiness of the final products, only a few and incomplete studies have been indeed performed about milk quality assessment to improve the potentiality productive of these ruminants. The Italian MB is considered as a different species than Brazilian and Indian buffaloes, so all the results achieved about milk quality in these species are poorly useful or requiring constant validations

Unfortunately the EU- Governments consider the MB as minor dairy specie and its importance is often underestimated; as consequence, limited international economic resources are dedicated for this specie; additional economic resources should be invested in order to improve the knowledge of dairy $\mathrm{MB}$ management, milk quality and safety guaranteeing at the time sale of a high quality dairy EU-product.
One of the most costly diseases afflicting MB's breeding system is represented by bacterial mastitis and Staphylococcus aureus ( $S$. aureus) is one of the most problematic. As recently described, $S$. aureus is one of the most important contagious pathogen causing mastitis in dairy buffalo such us in cows; considering its negative impact on milk quality and yield, it is considered cause of great economic losses for the dairy industry. Even mild intramammary infections (IMI) due to S. aureus can damage the developing secretory tissue leading decreased milk production followed by increased somatic cells count (SCC) and decreased in lactose concentration and milk yield. Specific treatments and an high standard management are necessary to resolve the "mastitis problem" in the herd, although the knowledge on antibiotic therapies in these ruminants is often very poor.

As reported by the World Health Organization (WHO, 1998) a reduction of the use of antibiotic in farm animals by mean of the verify of the prophylactic efficacy of farm specific vaccines should be encouraged. The emergence of antibiotic-resistant microorganisms in farm animal environments poses a potential public health concern; the use of antimicrobial agents on dairy farms as well as in other food animal production systems is a major concern in the emergence of resistant zoonotic bacterial pathogens. Although different antibiotic classes of drugs are used in animal health management and in human medicine, the selection of resistance to one drug class may lead to crossresistance to another; in this context, the use of other prophylactic measurement, such as the vaccines should be encouraged also in this dairy ruminant.

Therefore, it is important to support MB's dairy industry, promoting the production of high quality milk by means of deep and complete knowledge of the problem in order to establish an innovative approach to the clinical, diagnostic, epidemiological, prophylactic as well as biosecurity aspects of mammary infections in MB. 
This work is licensed under Creative

Commons Attribution 4.0 Licens

DOI: 10.19080/JDVS.2017.01.555557
Your next submission with Juniper Publishers will reach you the below assets

- Quality Editorial service

- Swift Peer Review

- Reprints availability

- E-prints Service

- Manuscript Podcast for convenient understanding

- Global attainment for your research

- Manuscript accessibility in different formats

( Pdf, E-pub, Full Text, Audio)

- Unceasing customer service

Track the below URL for one-step submission https://juniperpublishers.com/online-submission.php 